\title{
PEMURNIAN MINYAK JELANTAH MENGGUNAKAN ADSORBEN BERBASIS CANGKANG TELUR
}

\section{PURIFICATION OF USED COOKING OIL USING EGG SHELL BASED ADSORBENT}

\author{
Elbine Parawitasari Pardede*, Aprilia Mularen \\ Program Studi Teknik Kimia, Fakultas Teknologi Industri, ITN Malang \\ Jl. Bendungan Sigura-sigura, No. 2 Malang 65145 \\ *elbinepardede22@gmail.com
}

\begin{abstract}
Abstrak
Mengkonsumsi telur ayam di Malang tahun 2011 sebesar 986. 794 ton serta cangkang telur ayam jadi salah satu limbahnya. Tiap cangkang telur mempunyai 10.000 - 20.000 pori-pori sehingga diperkirakan bisa meresap sesuatu solut serta bisa digunakan bagaikan adsorben. Disamping itu isi terbanyak cangkang telur merupakan kalsium karbonat, dimana kalsium karbonat ini tercantum ke dalam adsorben polar. Pada riset ini cangkang telur diaktivasi secara fisika serta dimanfaatkan bagaikan adsorben buat merendahkan bilangan asam, bilangan peroksida serta kandungan air pada minyak jelantah. Proses adsorpsi minyak jelantah dicoba dengan alterasi masa adsorben 5, 6, 7, 8, 9, 10 gr serta waktu pengadukan 10, 20, 30, 40, 50 menit. Bersumber pada hasil riset diperoleh keadaan optimum untuk penyusutan bilangan asam, bilangan peroksida serta kandungan air. Bilangan asam, bilangan peroksida serta kandungan air yang diperoleh pada keadaan optimum sudah penuhi standar SNI 3741- 2013 untuk minyak goreng ialah 0, 6 miligram $\mathrm{KOH} / \mathrm{gram}, 10 \mathrm{meq}_{2} /$ kilogram serta $0,15 \%$.
\end{abstract}

\section{Kata kunci: Adsorpsi, Cangkang telur ayam, Minyak Jelantah}

\begin{abstract}
Consuming chicken eggs in Malang in 2011 amounted to 986.794 tons and chicken eggshells as one of the waste. Each eggshell has 10,000-20,000 pores so it is estimated that it can absorb some solute and can be used as an adsorbent. Besides that, the most eggshell content is calcium carbonate, where this calcium carbonate is listed as a polar adsorbent. In this research, eggshells were physically activated and used as an adsorbent to reduce the acid number, peroxide number and water content of used cooking oil. The adsorption process of used oil was tried by altering the adsorbent mass of 5,6 , $7,8,9,10$ grams and stirring time of $10,20,30,40,50$ minutes. Based on the research results, the optimum conditions for shrinkage of the acid number, peroxide number and water content were obtained. The acid number, peroxide number, and water content obtained at optimum conditions have met the SNI 3741-2013 standard for cooking oil, namely 0.6-milligram KOH / gram, 10 meq O2 / kilogram and $0.15 \%$.
\end{abstract}

Key words: Adsorption, Chicken Eggshell, Used Cooking Oil

\section{Pendahuluan}

Pada tahun 2011 asupan telur ayam di Kota Malang sebanyak 986.794 ton dan limbahnya berupa cangkang telur ayam (Febrianto, 2017). Sampah rumah tangga yang belum dimanfaatkan secara maksimal adalah cangkang telur. Cangkang telur sebenarnya hanya digunakan sebagai bahan baku industri seni. Terdapat 10.000-20.000 pori dalam setiap cangkang telur, sehingga diperkirakan dapat menyerap larutan dan dapat digunakan sebagai adsorben. Selain itu kalsium karbonat merupakan kandungan terbesar pada cangkang telur, dimana kalsium karbonat digunakan sebagai penyerap polar (Hajar, 2016).

Cangkang telur ayam yang dipanaskan $600^{\circ} \mathrm{C}$ mengandung sekitar 94 persen $\mathrm{CaCO}_{3}$ dan sebagian kecil $\mathrm{CaO}$, sehingga dapat digunakan sebagai adsorben. Cangkang telur tidak aktif memiliki luas permukaan $12.955 \mathrm{~m}^{2} / \mathrm{g}$, sedangkan $2.700 .978 \mathrm{~m}^{2} / \mathrm{g}$ adalah yang terpicu secara fisik pada $600 / \mathrm{g}$ (Fitriana, 2015). Cangkang telur akan diaktifkan secara fisik dan kemudian digunakan dalam minyak goreng bekas untuk menyerap bahan yang tidak diinginkan.

Indonesia, khususnya di Malang (Mariana, 2010). Minyak goreng bekas adalah nama minyak goreng yang digunakan dalam menggoreng lebih dari 3-4 kali. Berbagai formulasi menjadi parameter seperti kadar air 0,5 persen, densitas 0,8912 g / mL, asam lemak bebas (ALB) 4,71 persen, bau busuk agak, dan warna keruh kecoklatan pada minyak goreng bekas. Minyak goreng bekas dengan bahan ini sudah tidak layak pakai lagi. Jika dibuang, maka akan mencemari atmosfer. Itu akan gagal untuk 
meningkatkan konsistensinya; Minyak goreng bekas dapat digunakan kembali sebagai sabun, kosmetik karena bahan biodiesel (Fitriana, 2015).

Beberapa penelitian telah melakukan peningkatan kualitas minyak goreng bekas, antara lain Yustina (2011). Adsorpsi minyak goreng bekas menggunakan adsorben arang aktif sabut kelapa menggunakan sabut kelapa. Variabel yang digunakan adalah massa adsorben dan waktu kerja. Hasil terbaik diperoleh pada proses adsorpsi menggunakan massa arang aktif 10 gram, menghasilkan minyak dengan absorbansi 1,99 mek / kg PV dan absorbansi 0,244 absorbansi. Alamsyah (2017) melakukan penelitian untuk mengetahui kandungan asam lemak bebas minyak goreng bekas setelah pemurnian sebesar 0,284 persen dan kadar 6,4259 peroksida air 0,065 persen yaitu Pemurnian Minyak Goreng Bekas dengan Proses Adsorpsi Menggunakan Adsorben Zeolit dan Biji Kelor. (Fitriana, 2015), Pemanfaatan Kulit Telur Ayam Sebagai Adsorben Aktivasi Fisik untuk Meningkatkan Konsistensi Minyak Goreng hasil yang optimal pada proses pemindahan dengan menggunakan adsorben 9 gram dalam waktu 60 menit. Dengan bilangan asam 0,3923 $\mathrm{mg} \mathrm{KOH} / \mathrm{g}$ dan bilangan peroksida 7,516 mek O2 / kg.

Penelitian ini bertujuan untuk mengetahui kemampuan adsorben kulit telur ayam teraktivasi fisik dengan variasi massa adsorben dan waktu pengadukan dalam meminimalkan bilangan asam, bilangan peroksida, dan kadar air sesuai SNI 01-3741-2013.

\section{Teori}

Bagian terluar telur memiliki ketebalan 0,2-0,4 mm dengan lapisan yang keras dan mengandung kalsium karbonat (kapur) untuk melindungi bagian dalam telur. Di dalam cangkang telur, udara bisa bergerak melalui pori-pori. Bergantung pada jenis burungnya, warnanya berkisar dari putih hingga coklat. Namun, perbedaan warna tidak mempengaruhi penampilan telur. Cangkang telur ayam berwarna kekuningan hingga putih jingga, toska adalah telur bebek, dan putih dengan bintik jingga kehitaman adalah telur puyuh.

Telur (ayam boiler) memiliki kulit terluar yang halus dan sebagian berwarna coklat. Yang coklat lebih padat dari yang putih. Ternyata, telur berwarna coklat lebih awet dibanding telur putih. Sebagian besar pori pada telur biasa berada di ujung cangkang. Di bawah kulit, ditemukan kantung udara. Semakin jauh jaraknya, semakin rendah jumlah pori-porinya. Protein musin dilapisi dengan bagian luar cangkang telur (kutikula) yang mencegah cairan masuk ke pori-pori, tetapi aliran gas dapat melewati kutikula (Emma, 2005).

Tabel 1 Komposisi Nutrisi Cangkang Telur

\begin{tabular}{|l|l|l|}
\hline No & Nutrisi & Cangkang Telur (\% Berat) \\
\hline 1 & Air & $29-35$ \\
\hline 2 & Protein & $1,4-4$ \\
\hline 3 & Lemak Murni & $0,10-0,20$ \\
\hline 4 & Abu & $89,9-91,1$ \\
\hline 5 & Kalsium Karbonat & 90,9 \\
\hline 6 & Calsium & $35,1-36,4$ \\
\hline 7 & Fosfor & 0,12 \\
\hline 8 & Sodium & $0,15-0,17$ \\
\hline 9 & Magnesium & $0,37-0,40$ \\
\hline 10 & Pottasium & $0,10-0,13$ \\
\hline 11 & Sulfur & $0,09-0,19$ \\
\hline 12 & Alanin & 0,45 \\
\hline 13 & Arginin & $0,56-0,57$ \\
\hline
\end{tabular}

(Sumber: Warsy, 2016). 


\section{Adsorben}

Adsorben adalah bahan padat yang dapat menyerap komponen tertentu (cair atau gas) dari suatu fluida. Sebagian besar adsorben merupakan bahan berpori, dan daya adsorpsi terjadi pada dinding pori atau pada lokasi tertentu di dalam partikel (Roosdiana, 2017).

\section{Aktivasi}

Terbentuknya $\mathrm{CaO}$ diindikasikan dengan penurunan bahan reaksi sebagai fungsi suhu, berikut reaksi dekomposisi $\mathrm{CaCO} 3$ menjadi $\mathrm{CaO}$ :

$$
\mathrm{CaCO}_{3}(\mathrm{~s}) \rightarrow \mathrm{CaO}(\mathrm{s})+\mathrm{CO}_{2}(\mathrm{~g})
$$

Setelah temperatur $700^{\circ} \mathrm{C} \quad \mathrm{CaO}$ akan mulai menumpuk secara substansial dan sekitar temperatur kesetimbangan $850^{\circ} \mathrm{C}$ (Haryono, 2018) konversi $\mathrm{CaCO}_{3}$ menjadi $\mathrm{CaO}$ akan meningkat secara signifikan.

\section{Adsorpsi}

Adsorpsi adalah penyerapan pada permukaan suatu zat. Luas permukaan adsorben, ukuran partikel dan waktu kontak merupakan faktor yang berpengaruh terhadap proses adsorpsi (Asip, 2008):

\section{Minyak jelantah}

Minyak goreng yang berulang, diikuti dengan pemanasan, dapat menyebabkan kerusakan, seperti perubahan komposisi kimiawi minyak goreng. Terjadinya oksidasi komponen dalam minyak akibat pemanasan minyak goreng yang tinggi. Banyak komposisi yang menjadi parameter dalam minyak goreng bekas, antara lain kadar air 0,5 persen, densitas 0,8912 g/ mL, asam lemak bebas (ALB) 4,71 persen, bau agak anyir, dan cokelat keruh. Minyak goreng bekas yang sudah mengandung bahan ini sudah tidak layak pakai dan akan mencemari suasana jika dibuang, namun minyak goreng bekas tersebut dapat digunakan kembali sebagai bahan pembuatan sabun, kosmetik, dan biodiesel sehingga lebih konsistensinya (Fitriana, 2015)

\section{Pemurnian Minyak jelantah}

Zat yang digunakan sebagai adsorben adalah limbah cangkang telur ayam yang secara fisik dipicu untuk meningkatkan adsorpsi. Aktivasi fisik menurut Napitapulu (2009) dapat memperluas pori-pori dengan cara memutus ikatan kimiawi atau mengoksidasi molekul permukaan sehingga luas permukaan bertambah dan mempengaruhi kapasitas adsorpsi.

\section{Metodologi Penelitian}

Teknik yang digunakan untuk memurnikan minyak goreng yang digunakan adalah dengan menggunakan kulit telur yang teraktivasi secara fisik dengan mengatur massa adsorben dan lama kontak, dilanjutkan dengan pemeriksaan perubahan minyak goreng yang digunakan.

Variabel Penelitian

- Ukuran adsorben

- Material Bahan Baku

- Sampel

- Waktu Aktivasi

- Suhu Aktivasi

- Banyaknya Sampel

- Penetralan dengan KOH 15\% : $18 \mathrm{~mL}$

- Kecepatan Pengadukan $\quad: 8 \mathrm{rpm}$

Variabel bebas antara lain:

- Massa Adsorben

- Waktu pengontakan

: 2 jam

: $700^{\circ} \mathrm{C}$
: 30 mesh

: Cangkang Telur Ayam Petelur

: Minyak Goreng Bekas dari Warung Gorengan

: $500 \mathrm{~mL}$

: 6 gram, 7 gram, 8 gram, 9 gram, 10 gram

: 10 menit, 20 menit, 30 menit, 40 menit, 50 menit 


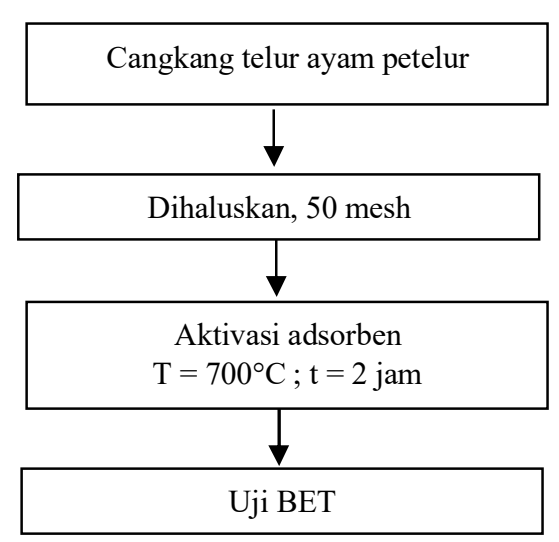

Gambar 1. Diagram Alir Penelitian

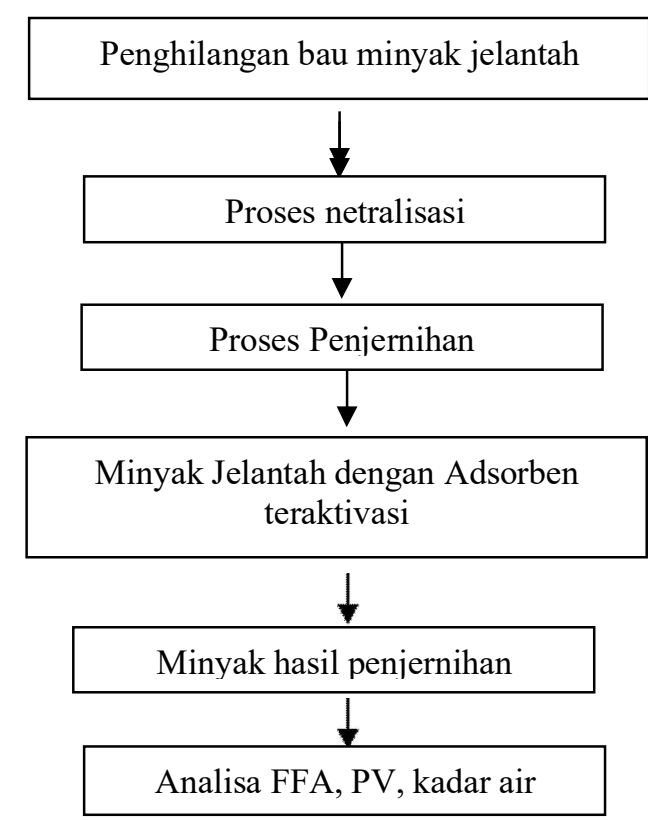

Gambar 2. Diagram Alir Pemurnian Minyak Jelantah Menggunakan Adsorben Berbasis Cangkang Telur.

Hasil

Analisa Awal Minyak Jelantah

- Bilangan Asam $\quad=7,3 \mathrm{mgKOH} / \mathrm{g}$

- Peroksida $=40$ mek O2/kg

- Kadar Air = 0,438 \% 


\section{Hasil Analisa Morfologi Adsorben dengan SEM}

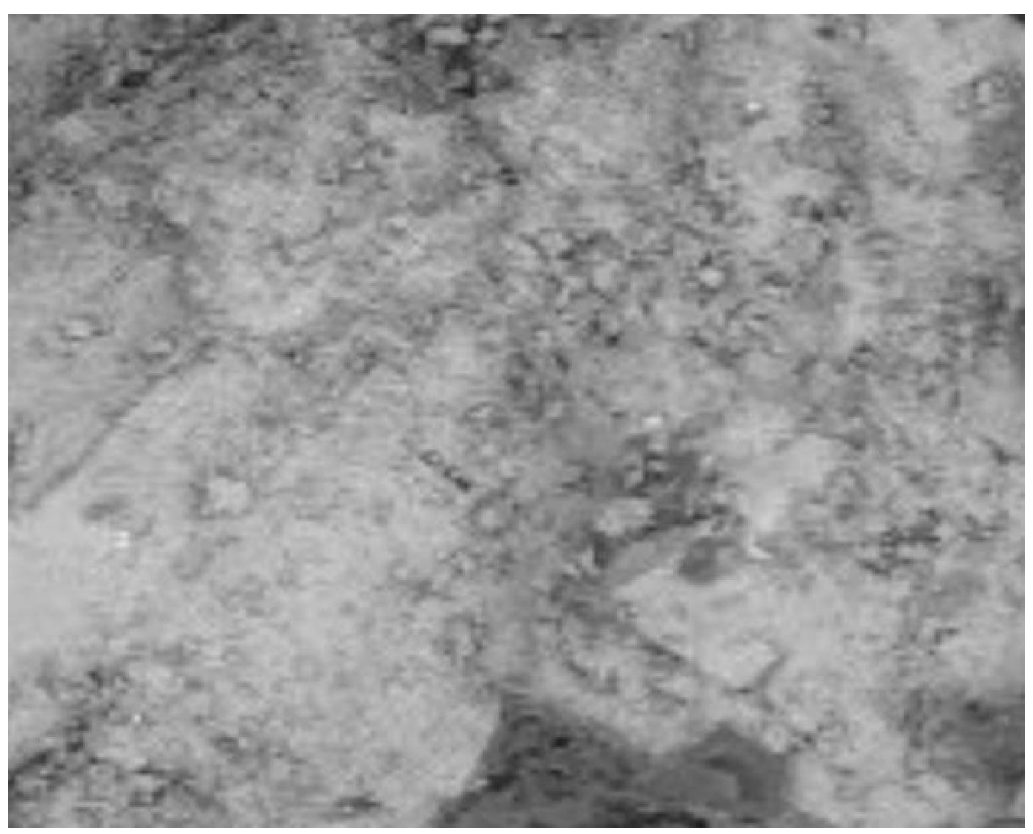

Gambar 3. Hasil analisa SEM sebelum aktivasi pada 30 mesh

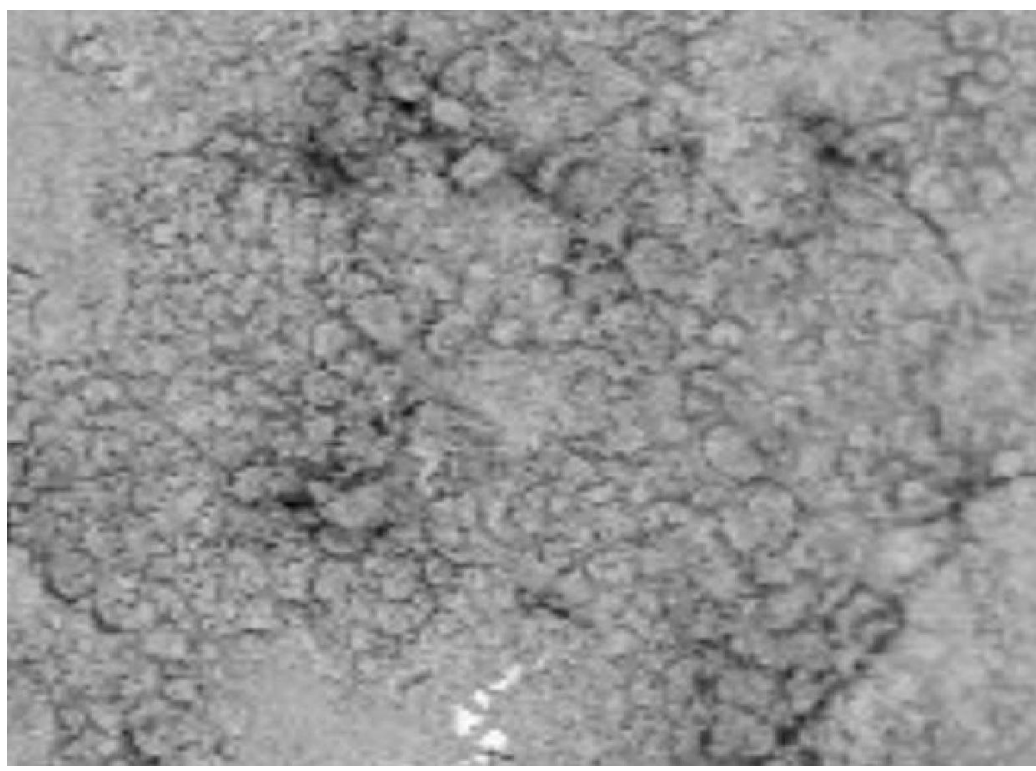

Gambar 4. Hasil analisa SEM setelah aktivasi pada 30 mesh

Analisis SEM telah digunakan untuk menentukan morfologi adsorben. Berdasarkan hasil ujian SEM, Gambar 3 menunjukkan cangkang telur berukuran 30 mesh. Dapat dibuktikan bahwa adsorben cangkang telur yang tidak aktif tidak memiliki celah dan rongga antar partikel. Di sisi lain, dapat dilihat pada Gambar 4. bahwa bentuk morfologi sampel adalah jarak antar partikel yang idealnya berongga, dimana ukuran partikel ditentukan oleh suhu yang meningkatkan energi kinetik atom sehingga terhubung satu sama lain (diaglomerasi). Proses absorpsi akan terjadi dengan rongga longgar dan jarak partikel. Larutan tersebut akan mengisi permukaan adsorben dan mengisi lubang kosong tersebut sehingga terjadi interaksi antara adsorben dengan sel (Hasfita, 2012). 


\section{Hasil analisis BET}

Tabel 2. Hasil analisa BET

\begin{tabular}{|c|c|c|}
\hline & Sebelum aktivasi & Setelah aktivasi \\
\hline Luas permukaan $\mathrm{m}^{2} / \mathrm{g}$ & 7.764 & 8.469 \\
\hline Volume pori cc/g & 1.1927 & 2.5144 \\
\hline
\end{tabular}

Hasil analisis BET adsorben 30 mesh sebelum dan sesudah aktivasi ditunjukkan pada Tabel 2. Hal ini dapat dijelaskan bahwa dengan aktivasi fisik menggunakan pemanasan pada suhu $700^{\circ} \mathrm{C}$ selama 2 jam, pori-pori adsorben terbuka. Ciri-ciri tersebut memberikan informasi bahwa cangkang telur ayam dapat digunakan sebagai adsorben karena memiliki luas permukaan dan volume pori yang cukup besar. Pada proses aktivasi cangkang telur digunakan temperatur $700^{\circ} \mathrm{C}$ selama 2 jam untuk membentuk $\mathrm{CaO}$ dimana $\mathrm{CaO}$ memiliki struktur berbentuk heksagonal yang memiliki grid di dalamnya diselingi dengan $\mathrm{H}$ + dan $\mathrm{Na}+$ dan lain-lain (Fitriana, 2015).

Model isoterm adsorpsi digunakan untuk memberikan gambaran tentang karakteristik adsorpsi pada permukaan adsorben dan interaksi antara adsorbat dan adsorben. Dari hasil analisis diketahui nilai R2 lebih dari 0,9. Besarnya energi adsorpsi yang diperoleh menunjukkan bahwa mekanisme proses adsorpsi adalah adsorpsi fisik yang disebabkan oleh gaya tarik menarik yang melibatkan gaya van der Waals dari interaksi dipol-pol terinduksi (Alimano, 2014).

\section{Analisa Bilangan Asam}

Bilangan asam yang diperoleh setelah proses adsorpsi dengan variasi massa adsorben dan waktu pengadukan mengalami penurunan, seperti terlihat pada Gambar 5.

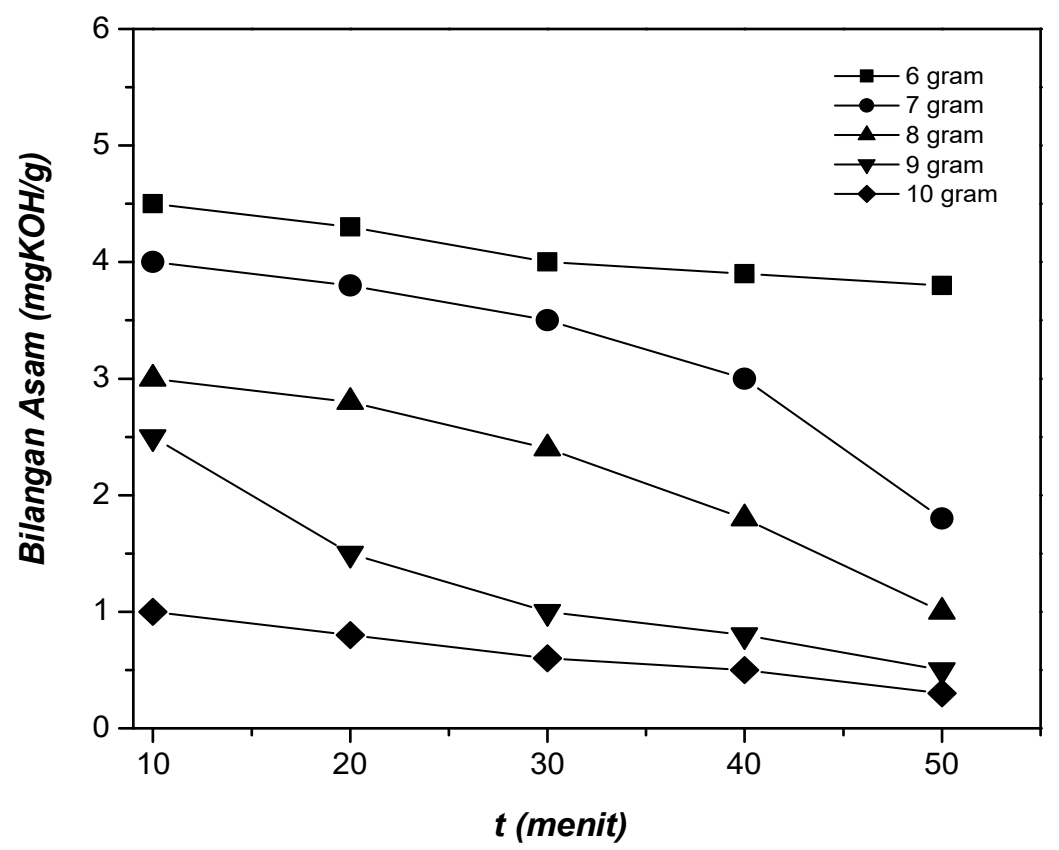

\section{Gambar 5. Bilangan Asam sampel pada variasi massa adsorben dan waktu pengadukan}

Dari Gambar 5, terlihat bahwa bilangan asam pada berbagai sampel mengalami kecenderungan yang sama yaitu mengalami penurunan ketika waktu pengadukan bertambah besar. Hal ini terjadi karena senyawa asam lemak bebas dengan ujung karboksil polar diserap dengan adsorben cangkang telur polar. Jika adsorben berlawanan maka komponen polar akan lebih kuat daripada bagian non polar (Jasinda, 2013). Penurunan bilangan asam dipengaruhi oleh jumlah adsorben dan lamanya kontak. Sesuai teori 
adsorpsi, semakin banyak adsorben dan semakin lama waktu kontak maka akan semakin cepat pula proses pemurniannya. Persentase penurunan bilangan asam maksimum yang diserap oleh adsorben adalah pada massa 10 gram dan waktu pengadukan 50 menit, yaitu $0,3 \mathrm{mgKOH} / \mathrm{g}$. Bilangan asam ini telah memenuhi standar SNI 01-3741-2013 minyak goreng.

Namun pada waktu kontak 40 dan 50 menit dengan massa adsorben 6 gram terjadi penurunan bilangan asam yang hampir konstan. Hal tersebut terjadi karena adsorben telah mengalami masa kejenuhan yang menyebabkan adsorben tidak lagi menyerap bilangan asam dalam minyak (Asip, 2008).

\section{Bilangan Peroksida (PV)}

Bilangan Peroksida yang diperoleh setelah proses adsorpsi dengan variasi massa dan waktu pengadukan mengalami penurunan, seperti terlihat pada Gambar 6.

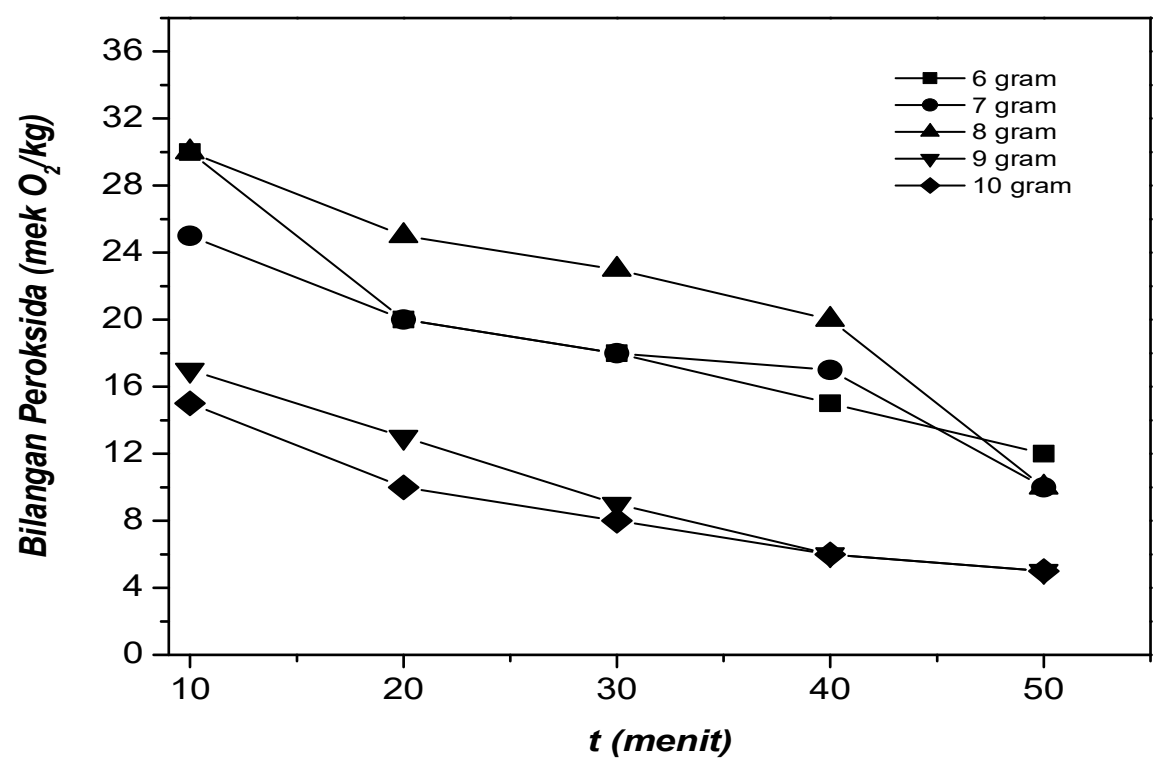

Gambar 6. Bilangan Peroksida sampel yang divariasi pada massa adsorben dan waktu pengadukan

Dari Gambar 6 terlihat bahwa bilangan peroksida pada berbagai sampel cenderung mengalami penurunan. Hal ini terjadi karena peroksida yang mengandung oksigen merupakan senyawa polar sehingga lebih mudah berikatan dengan adsorben cangkang telur polar. Jika adsorben berlawanan maka komponen polar akan lebih kuat daripada bagian non polar (Jasinda, 2013). Penurunan bilangan peroksida dipengaruhi oleh jumlah adsorben dan lamanya kontak. Hal ini berdasarkan teori dimana semakin banyak adsorben dan semakin lama waktu kontak maka semakin cepat pula proses pemurniannya. Penurunan bilangan peroksida yang paling masif adalah nilai peroksida sebesar 7 mek O2 / kg pada massa adsorben 10 gram dan waktu pengadukan 50 menit. Ini telah memenuhi standar SNI 01-3741-2013.

Namun pada waktu kontak 40 dan 50 menit dengan massa adsorben 10 gram penurunan bilangan peroksida tetap konstan. Hal tersebut terjadi karena adsorben telah mengalami masa kejenuhan yang menyebabkan adsorben tidak lagi menyerap bilangan asam dalam minyak (Asip, 2008).

\section{Tinjauan analisis kadar air}

Keberadaan air dalam minyak sangat tidak diinginkan karena akan menghidrolisis lemak menjadi asam lemak bebas yang tengik (Poedjiadi, 1999). Kadar air yang tinggi menurunkan efisiensi dan sampel berbau anyir. Penurunan kadar air pada sampel terlihat jelas dalam tampilan Gambar 7. 


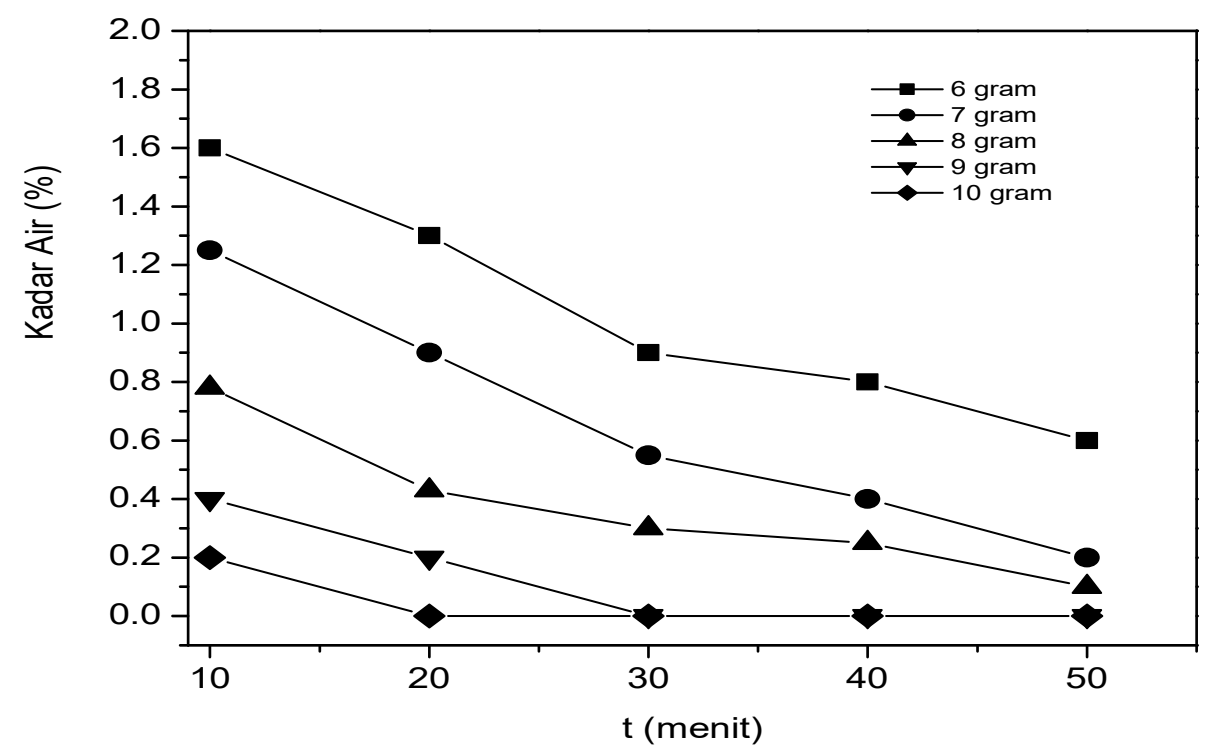

Gambar 7. Kadar Air dalam sampel (\%) setelah proses adsorpsi pada berbagai massa adsorben dan waktu pengadukan

Kecenderungan penurunan kadar air dalam sampel setelah proses adsorpsi dengan variasi waktu pengadukan terlihat dalam Gambar 7. Penurunan ini terjadi karena air adalah senyawa polar, sehingga lebih mudah mengikat kulit telur adsorben, sebaliknya. Jika adsorben bersifat polar maka bagian polar lebih kuat dibandingkan dengan unsur non polar (Jasinda, 2013). Penurunan kadar air dipengaruhi oleh jumlah adsorben dan panjang kontak. Hal ini dikarenakan semakin banyak adsorben dan semakin lama waktu kontak maka semakin cepat pula proses pemurniannya. Dan hasil yang paling penting adalah jumlah 0 persen dari 10 gram massa adsorben, dan waktu pengadukan adalah 50 menit. Itu memenuhi standar SNI 01-3741-2013. Namun pada waktu kontak 30, 40, dan 50 menit dengan massa adsorben 9 dan 10 gram, penurunan jumlahnya konstan. Pada menit ke-30, kandungan air telah terserap seluruhnya.

\section{Kesimpulan}

Selama 2 jam, adsorben cangkang telur terpicu pada $700^{\circ} \mathrm{C}$. Ini membuka struktur pori adsorben. Dari hasil analisis BET didapatkan bahwa luas permukaan setelah aktivasi lebih signifikan dibandingkan sebelum aktivasi dan volume pori. Sebelum dan sesudah aktivasi, luas permukaan adalah $7.764 \mathrm{~m} 2 / \mathrm{g}$ dan $8.469 \mathrm{~m} 2 / \mathrm{g}$ dan volume pori adalah $1.1927 \mathrm{cc} / \mathrm{g}$ dan $2.5144 \mathrm{cc} / \mathrm{g}$ sebelum dan sesudah aktivasi. Dari temuan tersebut dapat disimpulkan bahwa cangkang telur memiliki kapasitas adsorben. Metode adsorpsi pada minyak goreng bekas menggunakan adsorben kulit telur memberikan pengaruh yang besar. Massa adsorben dan waktu adsorpsi sangat mempengaruhi metode adsorpsi dalam pemurnian minyak goreng bekas. Semakin banyak adsorben yang digunakan dan semakin lama waktu adsorpsinya maka semakin tinggi kualitas minyak goreng yang digunakan. Hasil adsorpsi diperoleh bilangan asam terendah 0,3 $\mathrm{mgKOH} / \mathrm{g}$, bilangan peroksida 7 mek $\mathrm{O}_{2} / \mathrm{kg}$, dan kadar air 0 persen pada 50 menit, dan massa adsorben 10 gram. Dari hasil penelitian dapat disimpulkan bahwa massa adsorben dan waktu adsorpsi berpengaruh terhadap proses pemurnian minyak goreng bekas menggunakan adsorben cangkang telur.

\section{Daftar Pustaka}

Alamsyah. 2017. Pemurnian Minyak Jelantah Dengan Proses Adsorbsi. Journal of Chemical Process Engineering, Universitas Muslim Indonesia, Vol. 2, No. 2, 2017.

Alimano Marsen, Mindriany Syafila, 2014, Reduksi Ukuran Adsorben Untuk Memperbesar Diameter Pori Dalam Upaya Meningkatkan Efisiensi Adsorpsi Minyak Jelantah, Jurnal Teknik Lingkungan, ITB, Vol 20, No. 2 (2014).

F. Asip, dkk, 2008, Uji Efektifitas Cangkang Telur Dalam Mengadsorbsi Ion Fe Dengan Proses Batch, Jurnal Teknik Kimia, No. 2, Vol. 15, April 2008. 
Febrianto., Nanang, dkk. 2017. Proyeksi Elastisitas Telur Ayam Ras di Malang Raya. Jurnal Ilmu-Ilmu Peternakan, Universitas Brawijaya, Vol 27, No. 2, p. 81-87

Fitriana., Eka Safitri, 2015. Pemanfaatan Cangkang Telur Ayam Sebagai Adsorben Untuk Meningkatkan Kualitas Minyak Jelantah. Jurnal Konversi, Universitas Lambung Mangkurat, Volume 4 No. 1, April 2015

Hajar, Erna W. I., dkk. "Efektivitas Adsorpsi Logam Pb2+ Dan Cd2+ Menggunakan Media Adsorben Cangkang Telur Ayam." Jurnal Konversi UNLAM, vol. 5, no. 1, Apr. 2016, pp. 1-7.

Haryono., dkk. 2018. Kalsium Oksida Mikropartikel Dari Cangkang Telur Sebagai Katalis Pada Sintesis Biodiesel Dari Minyak Goreng Bekas. Jurnal Material dan Energi Indonesia, Universitas Padjajaran, Vol 8 No. 01, 2018.

Hasfita., Fikri. 2012. Study Pembuatan Biosorben dari Limbah Daun Akasia Mangium (Acacia Mangium Wild) Untuk Aplikasi Penyisihan Logam, Jurnal Teknologi Kimia Universitas Malikussaleh, Vol 1 No. 1 (2012).

Jasinda, 2013. Pembuatan dan Karakterisasi Adsorben Cangkang Telur Bebek yang Diaktivasi Secara Termal. Skripsi Sarjana, Universitas Sumatera Utara.

Mariana, 2010. Pemetaan Potensi Kota Malang Sebagai Pemasok Minyak Goreng Bekas Untuk Produksi Biodiesel. Jurnal Teknologi Dan Kejuruan, Universitas Negri Malang, Vol. 33, No. 2, 2010. P. 193-200

Poedjiadi., A. 1999. Dasar-dasar Biokimia. UI-Press: Jakarta.

Rahman., Nanik Astuti dan Setiyawati., Harimbi. 2012. Peningkatan Kadar Bioetanol dari Kulit Nanas Menggunakan Zeolit Alam dan Batu Kapur. Jurnal Teknik Kimia, UPN Veteran Jawa Timur, Vol. 6, No. 2, April 2012

Roosdiana dkk, 2017, Enzymatic Synthesis Of Cellulose Propionate And Its Potency As Raw Material For Membrane, Journal of Environmental Engineering and Sustainable Technology, Vol 4, No. 2, p. 74-77

Warsi., dkk. 2016. Optimalisasi Kalisium Karbonat dari Cangkang Telur Untuk Produksi Pasta Komposit. Jurnal Al-Kimia, Universitas Islam Negeri Alludin Makassar. Vol 4, No 2, 2016 